\title{
Seasonal variability in hydrologic-system response to intense rain events, Matanuska Glacier, Alaska, U.S.A.
}

\author{
Jon C. Denner, ${ }^{1}$ Daniel E. Lawson, ${ }^{2}$ Grahame J. Larson, ${ }^{3}$ Edward B. Evenson, ${ }^{4}$ \\ Righard B. Alley, ${ }^{5}$ Jeffrey C. Strasser, ${ }^{6}$ Sarah Kopgzynski ${ }^{7}$ \\ ${ }^{1}$ U. S. Geological Survey, Montpelier, VT 05601, U.S.A. \\ ${ }^{2}$ Cold Regions Research and Engineering Laboratory, Anchorage, AK 99505, U.S.A. \\ ${ }^{3}$ Department of Geological Sciences, Michigan State University, East Lansing, MI 48824, U.S.A. \\ ${ }^{4}$ Department of Earth and Environmental Sciences, Lehigh University, Bethlehem, PA 18015, U.S.A. \\ ${ }^{5}$ Earth System Science Center and Department of Geosciences, Pennsylvania State University, University Park, PA 18015, U.S.A. \\ ${ }^{6}$ Department of Geology, Augustana College, Rock Island, IL 61201, U.S.A. \\ ${ }^{7}$ Department of Earth Sciences, University of New Hampshire, Durham, NH 03824, U.S.A.
}

\begin{abstract}
Two rain events at Matanuska Glacier illustrate how subglacial drainage system development and snowpack conditions affect hydrologic response at the terminus. On 21 and 22 September 1995, over $56 \mathrm{~mm}$ of rain fell in the basin during a period usually characterized by much drier conditions. This event caused an 8-fold increase in discharge and a 47-fold increase in suspended-sediment concentration. Peak suspended-sediment concentration exceeded $20 \mathrm{~kg} \mathrm{~m}^{-3}$, suggesting rapid evacuation of stored sediment. While water discharge returned to its pre-storm level nine days after the rain ceased, suspendedsediment concentrations took about 20 days to return to pre-storm levels. These observations suggest that the storm influx late in the melt season probably forced subglacial water into a more distributed system. In addition, subglacially transported sediments were supplemented to an unknown degree by the influx of storm-eroded sediments off hillslopes and from tributary drainage basins.

A storm on 6 and 7 June 1997, dropped $28 \mathrm{~mm}$ of rain on the basin demonstrating the effects of meltwater retention in the snowpack and englacial and subglacial storage early in the melt season. Streamflow before the storm event was increasing gradually owing to warming temperatures; however, discharge during the storm and the following week increased only slightly. Suspended-sediment concentrations increased only a small amount, suggesting the drainage system was not yet well developed, and much of the runoff occurred across the relatively clean surface of the glacier or through englacial channels.
\end{abstract}

\section{INTRODUGTION}

A late-season rainstorm of tropical origin caused widespread flooding in south-central Alaska in September 1995. An early-season storm in 1997 provided a unique contrast to this larger event. Both storms' hydrologic and sedimentologic effects were monitored at the Cold Regions Research and Engineering Laboratory (CRREL) glacier research site at Matanuska Glacier, Alaska. As part of on-going research at the glacier, streamflow, meteorological, suspended-sediment and other data are collected during the melt season at the ice margin and at a stream gage about $500 \mathrm{~m}$ from the ice margin (Fig. 1). The storms provided a unique opportunity to study the effects of early- and late-season extreme events on a highly glacierized drainage basin. Hydrologic data collected through each melt season since 1994 served as a reference for evaluating the impacts of both storms.

The hydrologic characteristics of glacial drainage basins are markedly different than those for nonglacial basins (Meier, 1986). In nonglacial drainage basins, the seasonal snowpack melts in spring, generating a peak flow in late spring and early summer that is followed by recession and low flow. In glacierized drainage basins, most precipitation falls as snow and is stored as snow and ice. Glaciers delay runoff early in the melt period because of temporary englacial and subglacial storage of meltwaters (Fountain and Tangborn, 1985). The melting of glacier ice in July and

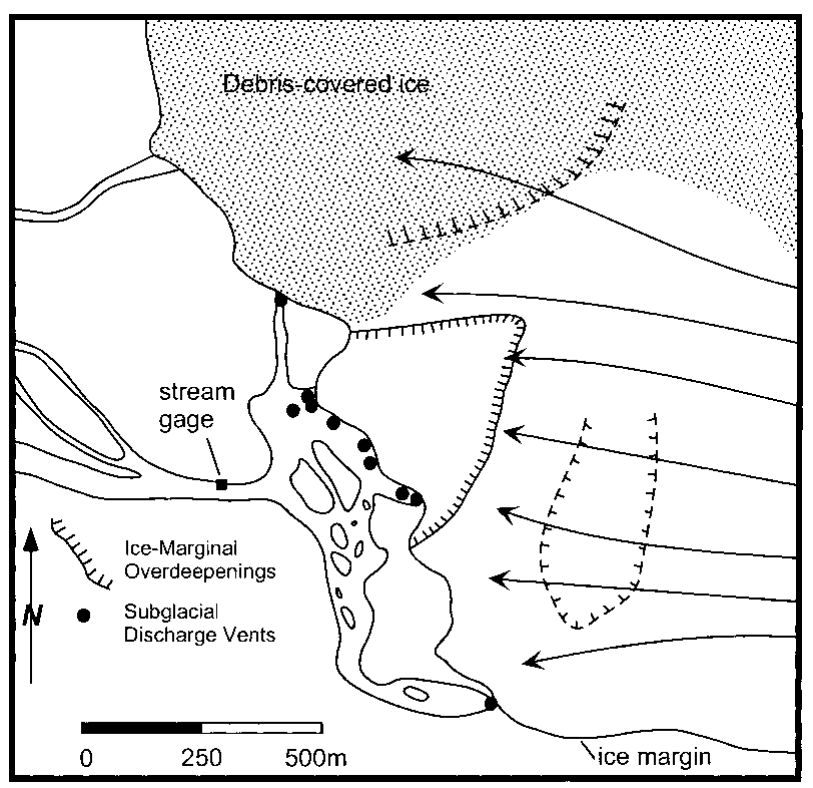

Fig. 1. Research site at Matanuska Glacier. 
August augments normal streamflow from ground water and snowmelt sources, so that the maximum seasonal flow is often produced during that time (Meier and Tangborn, 1961). Runoff from summer rainstorms is regulated to a large degree by flow through and storage in the glacier's drainage system (Lawson, 1993). Rainfall runoff may also be delayed because of retention in the remaining snowpack. Later in the summer, the combined icemelt, rain on ice, snowmelt from adjacent valley slopes and additional meltwater released by heat of rainfall (Röthlisberger and Lang, 1987), augment storm runoff and can produce a maximum flood discharge several days or more after the storm ends (Collins, 1995). In contrast, the runoff peak from storms in non-glacial basins typically occurs only a short time interval after the cessation of rainfall.

Sediment discharge from glacierized drainage basins is greatest in summer during periods of maximum glacial melting following some storms (Collins, 1989). Infrequent large storms can generate a significant fraction of the annual sediment yield in only a few days (Østrem, 1975). While there is no simple relationship between water discharge and sediment transport (Gurnell, 1987), suspended-sediment concentration generally increases or decreases in accordance with streamflow. Episodic release of sediment and various glaciohydrologic processes can significantly affect the streamflow/ suspended-sediment relationship (Lawson, 1993).

Availability of sediment affects sediment concentration in glacial meltwaters. Sediment carried by glacially-fed streams is derived from sediment transported by the glacier itself, sediment transported by meltwater within the englacial-subglacial drainage system, and sediment eroded and transported into the glacier's drainage system from tributary streams draining glacier-free areas of the basin (Lawson, 1993). Sediment flux reflects the degree of development of the internal drainage system (Iken and Bindschadler, 1986; Collins, 1989). In spring and early summer, new sediments deposited at the glacier bed in winter are entrained and removed as different areas are flushed out by the developing subglacial drainage system. Sediment concentrations decline late in the melt season because of reduced runoff, as well as in some cases, depletion of the subglacial sediment supply (Lawson, 1993). Only flood events generally cause large increases in sediment discharge then, because the increased water flow across the bed rapidly erodes any remaining subglacial sediments and runoff from valley walls and tributary streams produces an inwash of eroded materials (Evenson and Clinch, 1987). At Matanuska Glacier, the terminus overdeepenings are floored by sediment of $10 \mathrm{~m}$ or more in thickness (Lawson and others, 1998). During the September flood, numerous new discharge vents, fed by subglacial conduits, developed at the ice edge along the primary ice-marginal overdeepening (Fig. 1) and therefore these conduits had access to subglacial sediments. Each vent was also characterized by a rapid growth in frazil ice and sediment entrapment, associated with supercooled water temperatures during this period of high discharge (Alley and others, 1998).

\section{SETTING}

The Matanuska Glacier River basin originates in the Chugach Mountains of south-central Alaska, about 138 km northeast of Anchorage $\left(61^{\circ} 47^{\prime} \mathrm{N}, 147^{\circ} 45^{\prime} \mathrm{W}\right)$. The basin drains an area of $647 \mathrm{~km}^{2}$ north of the drainage divide of the Chugach
Mountains, where land-surface altitudes range from about $3600 \mathrm{~m}$ at the highest point to about $490 \mathrm{~m}$ at the glacier's terminus (Lawson, 1979). The Matanuska Glacier covers about $56 \%$ of the watershed. Two major tributaries flow out of the icefields to form the main body of the glacier at about $34 \mathrm{~km}$ from the terminus. Here the glacier is about $2.2 \mathrm{~km}$ wide, increasing to about $5.0 \mathrm{~km}$ at the terminus (Fig. 1).

\section{HYDROLOGY}

\section{September 1995 storm runoff}

Remnants of a tropical storm struck south-central Alaska on 19 September 1995. Widespread and intense rains fell from 20-21 September, causing scattered flooding over a large area. The peak flow of record occurred at 12 of $35 \mathrm{U}$. S. Geological Survey (USGS) gaging stations in southcentral Alaska. Rivers flowing into Knik Arm of Cook Inlet (Eagle River, Peters Creek, Knik River and Matanuska River) had peak discharges with recurrence intervals of greater than the 100 year flood (USGS, 1996, p. 3).

Hydrologic conditions at the terminus of Matanuska Glacier during early September were normal. Streamflow was receding from the summer maximum. An increase in temperature of about $4^{\circ} \mathrm{C}$ between 18-22 September was recorded at the terminus. Data at the gaging station (Fig. 1) showed only a small increase in discharge in response to the warm weather on 19 September (Fig. 2). Data provided by

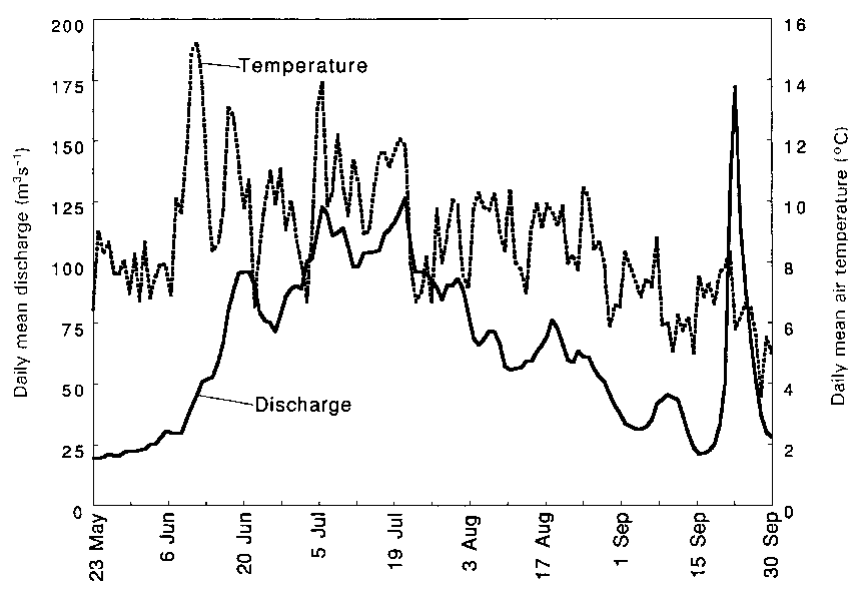

Fig. 2. Daily mean discharge and air temperature, Matanuska Glacier River, 1995.

the National Weather Service, National Oceanic and Atmospheric Administration (NOAA) indicated that the very warm temperatures resulted in unusually high freezing elevations (2700-3600 m) (NOAA, 1995). Precipitation from the storm therefore fell mostly as rain and not snow.

Precipitation at a meteorological site near the gaging station totaled $56 \mathrm{~mm}$ (Fig. 3). For this storm, it is assumed that nearly all the precipitation was rain; total rainfall over the upper part of the basin was estimated by NOAA at $152 \mathrm{~mm}$. The areal average rainfall totaled about $100 \mathrm{~mm}$ (NOAA, 1995).

Streamflow initially increased at a very slow rate in response to the rainfall during the 20-21 September storm. This lag reflects the regulating effects of the glacier and the distance between the source of intense runoff (high altitude on and off the glacier) and the gaging station. Peak discharge 


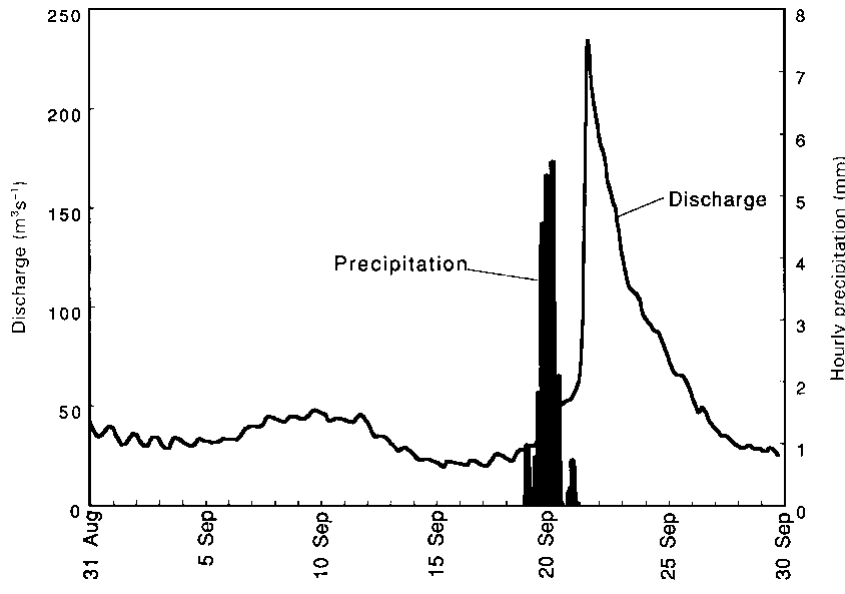

Fig. 3. Discharge and hourly precipitation, Matanuska Glacier River, 1995.

occurred at 1800 hours on 22 September, about 29 hours after the end of significant precipitation. The time-distribution of rainfall and the flood hydrograph indicate that not only was the flood peak delayed, but it was also attenuated and the flood recession prolonged for about nine days (Fig. 3).

The instantaneous peak flow recorded at the gaging station below the glacier was $234 \mathrm{~m}^{3} \mathrm{~s}^{-1}$ ( $5 \%$ standard error) on 22 September. This compares to the 1995 summer instantaneous peak of $143 \mathrm{~m}^{3} \mathrm{~s}^{-1}$ on 6 July, which occurred during very warm weather. Flood frequency for the September storm at the Matanuska Glacier was determined by using a multiple-regression analysis for estimating frequency of floods at ungaged sites in Alaska (Jones and Fahl, 1994). Application of this method resulted in an estimated recurrence interval of about 15 years.

Total specific storm runoff for 20-28 September was $100 \mathrm{~mm}$, the same as the estimated average rainfall over the watershed for the same time period. Because precipitation totals for the drainage basin are based on extrapolation, particularly at high altitudes, they are potentially subject to large errors. Hence, although runoff is based on accurate streamflow data recorded at the gaging station, an accurate water budget could not be calculated for the flood event. Furthermore, runoff in highly glacierized basins is a function of multiple factors including the nature of the glacier's drainage system and storage in it, meteorological parameters and water sources including ground water, compromising any such analysis.

\section{June 1997 storm runoff}

Prior to the June storm event, discharge had been increasing from about 11 to $20 \mathrm{~m}^{3} \mathrm{~s}^{-1}$ from mid-May to early June 1997. A warm spell just before the 6-7 June rains drove discharge upward to over $30 \mathrm{~m}^{3} \mathrm{~s}^{-1}$ (Fig. 4). Rainfall started early on 6 June and continued for about 48 hours (Fig. 5). Recorded precipitation at the meteorological site totaled $28 \mathrm{~mm}$. The June storm was not as intense as the September event, with $50 \%$ less precipitation accumulated at the terminus.

Discharge increased during the storm, but no distinct flood peak appeared on the hydrograph (Fig. 5) and the general upward trend in flow continued unabated after the event. The typical strong diurnal peak in discharge is only slightly higher during and following the rainfall, but the daily drop in discharge is nearly eliminated. Warm overnight temperatures, coupled with more local runoff, prob-

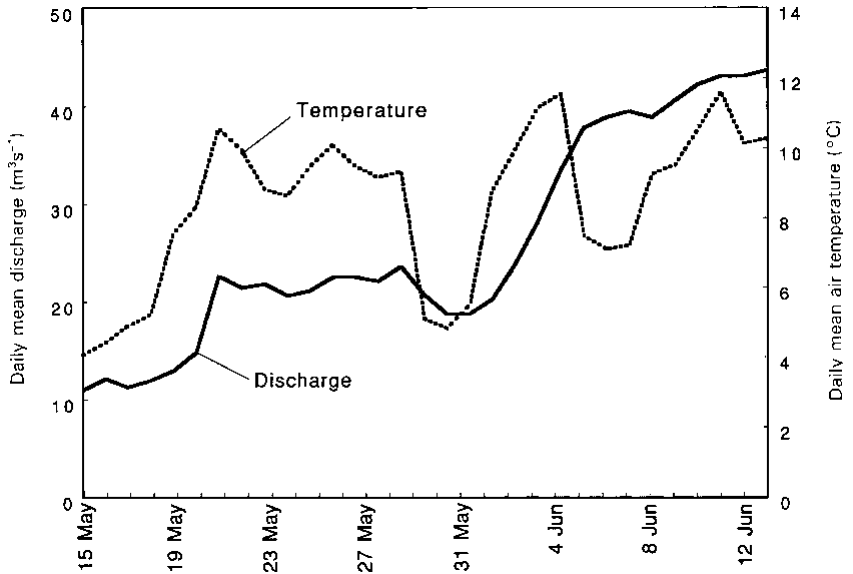

Fig. 4. Daily mean discharge and air temperature, Matanuska Glacier River, 1997.

ably enhanced discharge during the night to reduce the diurnal variability. The overall impact of the storm was minimized by conditions on and below the glacier; the remaining snowpack, which extended to within a kilometer of the terminus, and the state of the englacial and subglacial drainage system attenuated runoff in the upper glaciated area of the basin.

\section{STREAM SEDIMENT}

\section{September 1995 storm sediment}

In early September, the suspended-sediment concentration, like streamflow, was declining from its mid-summer maximum. The monthly mean concentration for July was $1.6 \mathrm{~kg}$ $\mathrm{m}^{-3}$, but fell to about $0.5 \mathrm{~kg} \mathrm{~m}^{-3}$ at the gaging station in early fall. Suspended-sediment concentration increased slightly in response to rainfall and runoff on 20 September (Fig. 6).

A sharp rise in suspended-sediment concentration occurred on 21 September, followed by a more dramatic increase on 22 September. The daily mean increased from $0.5 \mathrm{~kg} \mathrm{~m}^{-3}$ to $21.0 \mathrm{~kg} \mathrm{~m}^{-3}$. The corresponding daily mean discharge increased from $24.9 \mathrm{~m}^{3} \mathrm{~s}^{-1}$ on 19 September to $172 \mathrm{~m}^{3} \mathrm{~s}^{-1}$ on 23 September. The peak in sediment concentration occurred one day before the streamflow peak. This peak was unexpected because the sediment supply gradually diminishes during the melt period and is at a minimum by

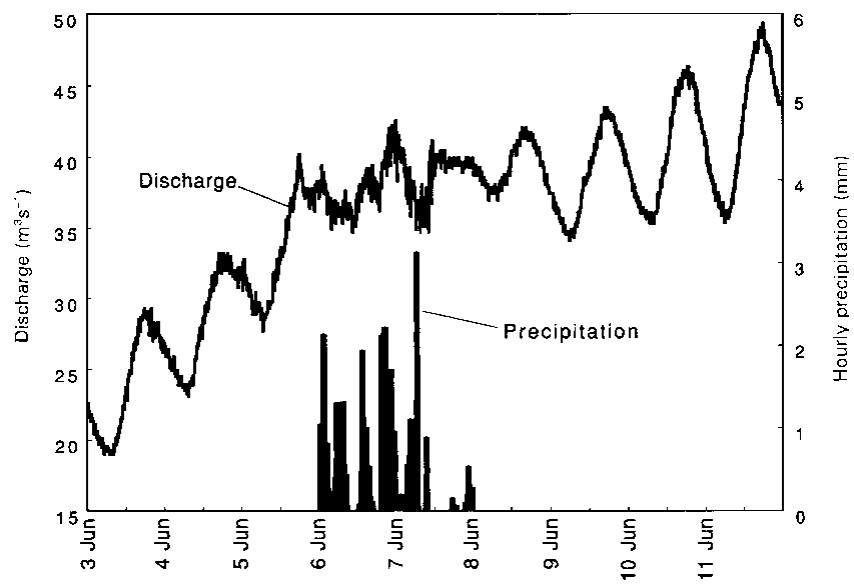

Fig. 5. Discharge and hourly precipitation, Matanuska Glacier River, 1997. 


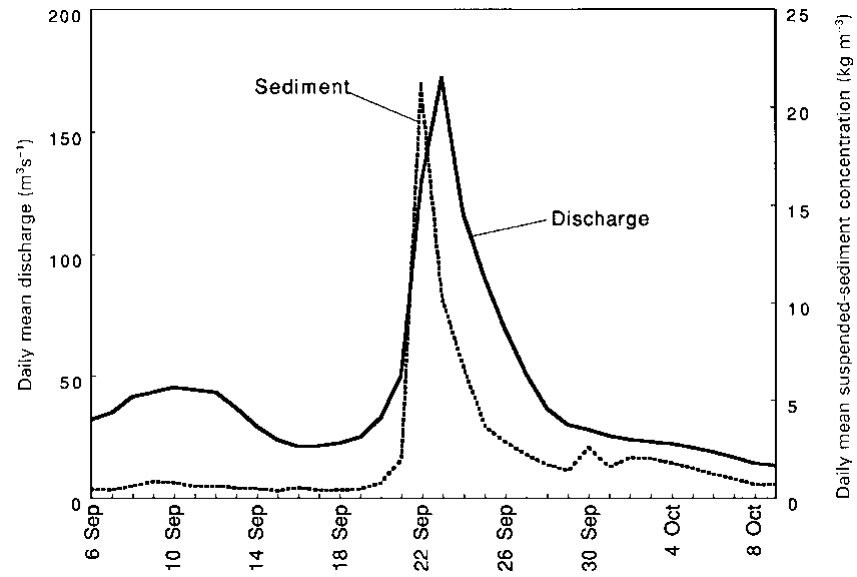

Fig. 6. Daily mean discharge and suspended sediment, Matanuska Glacier River, 1995.

early fall. The rapid mobilization of sediment suggests that increased water flow flushed out material from the sedimentary bed of the glacier, accessing areas that were not previously drained by subglacial conduits. Streamflow receded to pre-storm levels nine days after the storm began, but suspended-sediment concentration remained elevated until at least 9 October (some 23 days later), the last day samples were collected.

These findings demonstrate the importance of infrequent large storms in producing high suspended-sediment concentrations in streams draining glacierized basins and thereby increasing sediment flux to the margin. The maximum daily mean discharge on 23 September was $36 \%$ larger than the summer peak in daily mean discharge during July. In contrast, the daily mean suspended-sediment concentration during the flood event was $430 \%$ larger than the maximum daily mean concentration in July. We suspect this high concentration resulted from expansion of the subglacial drainage system and erosion of sediments from parts of the bed which were not previously covered by it. In addition, the presence of exposed valley slopes during this lateseason storm may also account for the larger sediment yields, when compared to the early-season storm in 1997. Overland flow, and thus sediment entrainment, may have been substantially higher during the September flood event.

\section{June 1997 storm sediment}

Pre-storm water discharge increased gradually, but suspended-sediment concentration varied widely and sporadically, with daily mean values ranging from 0.4 to $2.5 \mathrm{~kg} \mathrm{~m}^{-3}$ (Fig. 7). Overall, sediment concentration increased along with streamflow from 2-6 June, but then declined during and for a short period after the rainstorm. Mean concentration for a two-week period after the event was only $15 \%$ higher than for the two-week period before it. Unlike the sharp increase observed during the September 1995 flood, no peak in suspended-sediment concentration was detected during or following the June rainstorm.

The small increase in suspended-sediment concentration prior to the rainfall apparently reflects the under-developed condition of the glacial drainage system and the resultant small water flux. Large amounts of sediment built up over the previous winter are potentially available for flushing out in spring, but this source apparently is not fully exploited until later in the melt season as the subglacial drainage

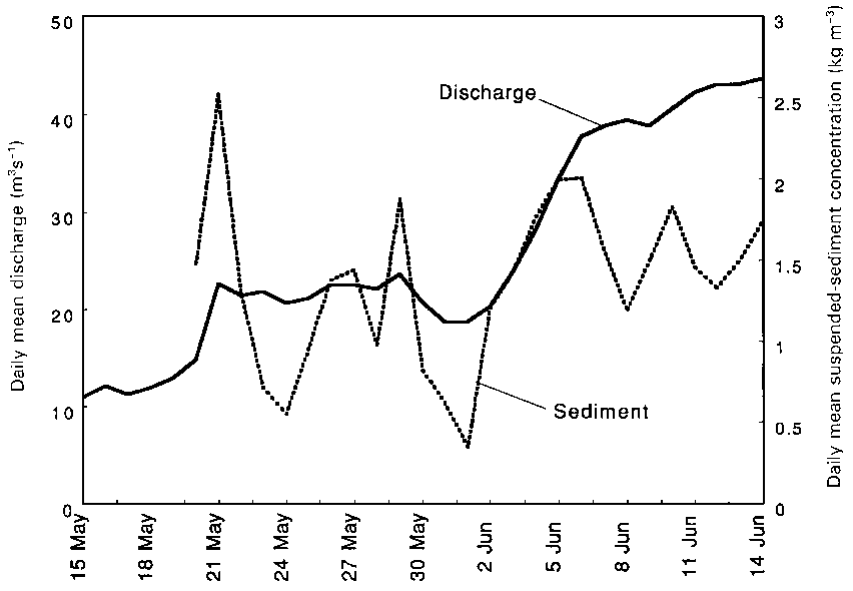

Fig. 7. Daily mean discharge and suspended sediment, Matanuska Glacier river, 1997.

system expands to cover a larger area of the glacier bed. Moreover, the occurrence of a deep snowpack on the valley slopes precluded erosion by overland flow, and therefore eliminated a potential source of sediment.

The downward trend in concentration during and following the event may be caused at least in part by dilution; a large fraction of both the normal runoff of meltwater and of that generated by rain falling on ice and snow was surface runoff over glacier ice. This runoff carried minimal amounts of sediment to ice-marginal streams. The small increase in suspended-sediment yield probably reflects the overall increase in the subglacial component of flow through the period.

\section{SUMMARY AND GONCLUSIONS}

The late-season rainstorm that struck south-central Alaska in September 1995 had a profound impact on the hydrology and sedimentation of the Matanuska Glacier River basin. The storm occurred late in the melt season, when streamflow and suspended-sediment concentrations were receding from their summer maximums. Excessive rainfall and warm weather combined to generate runoff that overwhelmed the temporary storage capacity of the glacier. Observations and measurements at vents fed by subglacial conduits at the terminus indicated a dramatic increase in water discharge and suspended-sediment concentration during the flood event. These data suggest that a rapid inflow of water into the subglacial drainage resulted in expansion of the drainage network and increased the removal of bed materials. Accelerated erosion of material from the exposed uplands probably provided an additional source of sediment.

Daily mean discharge at the gaging station during the 1995 flood peak exceeded the summer daily maximum by $36 \%$. Flows receded to pre-storm levels nine days after the rainstorm. In contrast, daily mean suspended-sediment concentration was $430 \%$ larger than the July daily peak (summer maximum). Suspended-sediment concentration did not return to pre-storm levels until more than 23 days after the event.

The early melt season rainstorm of June 1997 demonstrated the meltwater-retention effects of the snowpack and englacial storage capacity. Streamflow and suspended-sediment concentration at the gaging station showed only small 
increases in response to the rainstorm. This muted runoff response suggests that the englacial drainage system was not well developed; little water reached the subglacial drainageways, and the water that did reach the bed went into temporary storage there.

Together, the events show the variability of the hydrologic and sedimentologic response to early- and late-season rainstorms in a glaciated basin. The different responses are primarily dependent on the degree of development of subglacial/englacial drainage systems and on the areal extent of the snowpack.

\section{ACKNOWLEDGEMENTS}

This research was supported by the Army Corps of Engineers Civil Works Water Resources Program. We thank A. Iken and an anonymous reviewer for their suggestions and help in significantly improving this manuscript. Our thanks also to B. and K. Stevenson for continuing assistance and support of our research projects.

\section{REFERENGES}

Alley, R. B., D. E. Lawson, E. B. Evenson, J. C. Strasser and G. J. Larson. 1998. Glaciohydraulic supercooling: a freeze-on mechanism to create stratified, debris-rich basal ice. II. Theory. F. Glaciol., 44(148), 562-568.

Collins, D. N. 1989. Seasonal development of subglacial drainage and suspended sediment delivery to melt waters beneath an Alpine glacier. Ann. Glaciol., 13, 45-50.

Collins, D. N. 1995. Rainfall-induced high-magnitude runoff events in late summer in highly-glacierised Alpine basins. In BHS 5th National Hydrology Symposium, Edinburgh, 1995. British Hydrological Society, 3.55-3.59.

Evenson, E. B. and J. M. Clinch. 1987. Debris transport mechanisms at active alpine glacier margins: Alaska case studies. In Kujansuu, R. and
M. Saarnisto, eds. INOUA Till Symposium, Finland 1985. Espoo, Geological Society of Finland, 111-136. (Geol. Surv. Finl. Spec. Pap. 3.)

Fountain, A. G. and W. Tangborn. 1985. The effects of glaciers on streamflow variations. Water Resour. Res., 21 (4), 579-586.

Gurnell, A. M. 1987. Suspended sediment. In Gurnell, A. M. and M. J. Clark, eds. Glacio-fluvial sediment transfer: an alpine perspective. Chichester, etc., John Wiley and Sons, 305-354.

Iken, A. and R. A. Bindschadler. 1986. Combined measurements of subglacial water pressure and surface velocity of Findelengletscher, Switzerland: conclusions about drainage system and sliding mechanism. F. Glaciol., 32(110), 101-119.

Jones, S. H. and C. B. Fahl. 1994. Magnitude and frequency of floods in Alaska and conterminous basins of Canada. U.S. Geol. Surv. Water-Resour. Invest. Rep. 93-4179.

Lawson, D. E. 1979. A sedimentological analysis of the western terminus region of the Matanuska Glacier, Alaska. CRREL Rep. 79-9.

Lawson, D. E. 1993. Glaciohydrologic and glaciohydraulic effects on runoff and sediment yield in glacierized basins. CRREL Monogr. 93-02.

Lawson, D. E., J. G. Strasser, E. B. Evenson, R. B. Alley, G. J. Larson and S. A. Arcone. 1998. Glaciohydraulic supercooling: a freeze-on mechanism to create stratified, debris-rich basal ice. I. Field evidence. f. Glaciol., 44(148), 547-561.

Meier, M. F. 1986. Snow, ice, and climate: their contribution to water supply. U.S. Geol. Surv. Water-Supply Pap. 2300, 69-82.

Meier, M. F. and W.V. Tangborn. 1961. Distinctive characteristics of glacier runoff. U.S. Geol. Surv. Prof. Pap. 424-B, B14-B16.

National Oceanic and Atmospheric Administration (NOAA). 1995. South central Alaska floods September 19-October 2, 1995. Boulder, CO, U.S. Department of Commerce. National Oceanic and Atmospheric Administration. National Weather Service. (Flood Report.)

Østrem, G. 1975. Sediment transport in glacial meltwater streams. In Jopling, A.V. and B.C. McDonald, eds. Glaciofluvial and glaciolacustrine sedimentation. Tulsa, OK, Society of Economic Paleontologists and Mineralogists, 101122. (SEPM Special Publication 23.)

Röthlisberger, H. and H. Lang. 1987. Glacial hydrology. In Gurnell, A.M. and M.J. Clark, eds. Glacio-fluvial sediment transfer: an alpine perspective. Chichester, etc., John Wiley and Sons, 207-284.

United States Geological Survey (USGS). 1996. Water resources data for Alaska, water year 1995. Washington, DC, United States Geological Survey. (Water-Data Reports AK-95-1.) 